\title{
REASONS WHICH LEAD THE HEALTH SERVICES NOT TO ALLOW THE PRESENCE OF THE BIRTH COMPANION: NURSES' DISCOURSES
}

\author{
Odaléa Maria Brüggemann1ㅡ, Erika Simas Ebsen², Maria Emilia de Oliveira ${ }^{3}$, Marina Kuchiniski Gorayeb4, \\ Romana Raquel Ebele ${ }^{5}$
}

\begin{abstract}
${ }^{1}$ Ph.D in Obstetrics and Gynecology. Professor of the Department of Nursing and the Postgraduate Program in Nursing (PEN) at the Federal University of Santa Catarina (UFSC). Santa Catarina, Brazil. Researcher for the National Council for Scientific and Technological Development (CNPq). Email: odalea.ufsc@gmail.com

${ }^{2}$ Master's student, PEN/UFSC. CNPq Grantee. Santa Catarina, Brazil. Email: erikaebsen@gmail.com

${ }^{3}$ Ph.D in Nursing. Professor (rtd.) of the Department of Nursing, UFSC. Santa Catarina, Brazil. Email: mila_enfermagem@ yahoo.com.br

${ }^{4}$ Student on the Undergraduate Course in Nursing, UFSC. Scientific Initiation Grantee PIBIC/CNPq - 2013.1. Santa Catarina, Brazil. Email: marinagorayeb@hotmail.com

${ }^{5}$ Student on the Undergraduate Course in Nursing, UFSC. Scientific Initiation Grantee PIBIC/CNPq - 2013.2 Santa Catarina, Brazil. Email: romanaebele@gmail.com
\end{abstract}

\begin{abstract}
This qualitative research aimed to investigate the reasons the health services of Santa Catarina, Brazil, do not allow the presence of the birth partner of choice of women in the birthing process. The data were collected from September 2011 to January 2012 through semi-structured interviews with 12 nurses responsible for obstetric centers which did not permit, or permitted sometimes, the presence of the birth companion. The interviews were analyzed using the Discourse of the Collective Subject, in which three themes emerged: professionals' resistance to the presence of the companion; lack of physical infrastructure and human and material resources; and the institution's resistance to implementing the Companion's Law. The discourses show that impeding the presence of the companion is mainly related to the decision of the professionals and the inadequacy of the organizational structure. This requires changes in the attitude of the staff, institutional support, and management strategies to increase the support for the presence of the woman's companion of choice.
\end{abstract} KEYWORDS: Humanizing delivery. Social support. Patient rights. Obstetric nursing. Women's health.

\section{MOTIVOS QUE LEVAM SERVIÇOS DE SAÚDE A NÃO PERMITIREM ACOMPANHANTE DE PARTO: DISCURSOS DE ENFERMEIROS}

RESUMO: Pesquisa qualitativa, que objetivou compreender os motivos que levam os serviços de saúde de Santa Catarina, Brasil, a não permitirem a presença do acompanhante de escolha da mulher no processo parturitivo. Os dados foram coletados de setembro de 2011 a janeiro de 2012, por meio de entrevistas semiestruturadas com 12 enfermeiros responsáveis pelos centros obstétricos dos serviços que não permitiam ou permitiam às vezes o acompanhante. As entrevistas foram analisadas segundo o método do Discurso do Sujeito Coletivo, emergindo três temas: os profissionais são resistentes à presença do acompanhante; falta de estrutura física, recursos humanos e materiais; e a instituição é resistente na implementação da Lei do Acompanhante. Os discursos demonstram que o impedimento da presença do acompanhante está relacionado, principalmente, à decisão dos profissionais e com a inadequação da estrutura organizacional, requerendo mudanças na atitude da equipe, apoio institucional e estratégias de gestão que valorizem o apoio pelo acompanhante de escolha da mulher. PALAVRAS CHAVE: Parto humanizado. Apoio social. Direitos do paciente. Enfermagem obstétrica. Saúde da mulher.

\section{MOTIVOS QUE LLEVAN A LOS SERVICIOS DE SALUD A NO PERMITIR AL ACOMPAÑANTE EN EL PARTO: DISCURSOS DE ENFERMEROS}

\begin{abstract}
RESUMEN: Investigación cualitativa, que objetivó comprender los motivos que llevan a los servicios de salud de Santa Catarina, Brasil, a no permitir la presencia del acompañante elegido por la mujer en el parto. Los datos fueron recolectados de setiembre/2011 a enero/2012, por medio de entrevistas semiestructuradas con 12 enfermeros responsables por los centros obstétricos que no permitían o permitían algunas veces al acompañante. Las entrevistas fueron analizadas según la propuesta del Discurso del Sujeto Colectivo, emergiendo tres temas: los profesionales son resistentes a la presencia del acompañante; falta de estructura física, recursos humanos-materiales; falta de apoyo institucional para la implementación de la ley del acompañante. Los discursos demuestran que el no permiso del acompañante está relacionado principalmente con la decisión de los profesionales y con la inadecuada estructura organizacional, requiriendo cambios en la actitud del equipo, apoyo institucional y estrategias de gestión que valoricen el apoyo del acompañante elegido por la mujer.
\end{abstract}

PALABRAS CLAVE: Parto humanizado. Apoyo Social. Derechos del Paciente. Enfermería obstétrica. Salud de la Mujer. 


\section{INTRODUCTION}

In Brazil, since 2005, Law N. 11,108, known as the "Companion's Law" has obliged the health services to allow the presence of a companion, chosen by the parturient woman, throughout the period of labor and birth and the immediate postpartum period. ${ }^{1}$ So as to regulate the companion's presence in the public and private ambit, other documents were published such that this right might be guaranteed to all parturient women.

In the public ambit, in 2005, Ministerial Ordinance n. 2,418, of the Ministry of Health (MS, as per its acronym in Portuguese), authorized the payment of expenses to do with the companion during the birthing process, including the costs of appropriate accommodation and the provision of the main meals. ${ }^{2}$ In 2008, Collegiate Directive Resolution (RDC) n. 36, which establishes the Technical Regulations for the Functioning of the Obstetric and Neonatal Care Services, as well as re-affirming the woman's right to the companion, established parameters such that the services might ensure an appropriate and safe physical structure for the companions and workers. ${ }^{3}$ In the private sector, in 2010, the National Agency for Supplementary Health Services determined, through Normative Resolution n. 211, that obstetric attendance, regardless of the health insurance plans involved, shall cover all the expenses relating to the companion. ${ }^{4}$

It should be borne in mind that the right to a companion was provided for in the Program for Humanization of Pre-Natal Care and Childbirth, launched in $2000,{ }^{5}$ prior to the publication of the Companion's Law, ${ }^{1}$ and that at the present time it is also reinforced in the directives of the Stork Network*, a policy directed at care for women's health, instituted in $2011 .^{6}$

The discussions on the importance of ensuring the parturient woman the presence of a companion are supported by experimental studies and systematic reviews, undertaken in various countries since the 1980s, which present the beneficial effects of this support during labor and childbirth. ${ }^{7}$ These studies contributed to the World Health Organization's (WHO) recommendation that the parturient woman should be accompanied by somebody of her choice and whom she trusts, as this practice contributes to the humanization of care and to the reduction of obstetric interventions. ${ }^{8}$ Its main benefits are: an increase in spontaneous vaginal births; and reductions in intrapartum analgesia, the duration of labor, dissatisfaction with the experience of birth, cesarean births, instrumental vaginal births and births with low Apgar scores in the fifth minute of life. ${ }^{9}$

It should be emphasized that in the systematic review published in the Cochrane Library, ${ }^{9}$ updated in 2012, of the 22 randomized clinical trials analyzed, six evaluated the support for the companion from the woman's social network, these being undertaken in Botswana, Chile, the United States of America (New Jersey), Brazil, Nigeria and Thailand. The results of the clinical trial undertaken in Brazil, ${ }^{10}$ with 212 parturient women (105 in the intervention group - with a companion of the woman's choice, and 107 in the control group), indicated greater global satisfaction among the parturient women in the intervention group, regarding the experience of both the labor and the birth. The parturient women are more satisfied with the care received during labor (RR 1.11; CI 95\% 1.01-1.22), with the medical advice during labor (RR 1.14; CI 95\% 1.01-1.28), with the care received during birth (RR 1.11; CI 95\% 1.01-1.22) and with the vaginal birth (RR 1.33; CI $95 \%$ 1.02-1.74). ${ }^{10}$

However, in spite of the scientific evidence $^{7,9-10}$, of the WHO recommendations ${ }^{8}$, and of the Law ${ }^{1}$ in various Brazilian maternity centers, the parturient women are still deprived of the presence of a companion, ${ }^{11}$ as these new subjects provoke negative reactions in the professionals ${ }^{12-13}$ and in the health services. ${ }^{11}$

In this context, it becomes important to investigate why the health services do not adopt this practice, which contributes to improving the maternal and neonatal health indicators and the woman's satisfaction with the experience of childbirth. ${ }^{9-10}$ Thus, this study aimed to understand the reasons which lead the health services of Santa Catarina, Brazil, not to allow the presence of the parturient woman's companion of choice during labor, birth and the immediate postpartum period.

\section{METHOD}

This qualitative exploratory-descriptive research is part of the macro-project entitled "The insertion of the companion during labor, birth and

\footnotetext{
* The Stork Network is a strategy of the Brazilian Ministry of Health. In principle it ensures pregnant women a number of rights, including to a companion of their choice during the birth. Translator's note.
} 
the postpartum period: the reality in the state of Santa Catarina", with a mixed methodological approach. ${ }^{14}$ In the quantitative stage, undertaken in 2011, it was identified that, of the 135 health services linked with the Unified Health System (SUS, as per its acronym in Portuguese) which provide childbirth assistance in Santa Catarina, Brazil, 15 never allow the presence of the parturient woman's companion of choice during labor, birth and the immediate postpartum period, while 44 permit this only sometimes. ${ }^{15}$

Following this stage, the qualitative approach was undertaken, whose sample was made up of 12 health services (four of which did not allow the companion and eight of which allowed the companion to be present sometimes), in which the nurse responsible for the sector of the obstetric center in each service was interviewed. The number of services was defined during data collection, based on data saturation; that is to say, data collection ceased when the information began to be repeated or when what was added was little significant in view of the objectives proposed by the research. ${ }^{16}$ In selecting the participants, six of the eight regions in that State were covered. Data collection was undertaken between September 2011 and January 2012, using semi-structured interviews (using thematic scripts) arranged beforehand by telephone and email. Due to the geographical locality of the services, the interviews were held over the telephone and were recorded using a unidirectional microphone and a microcomputer equipped with a sound editing program. ${ }^{17}$

When first contacted, the nurses were informed about the objectives, methodology, and ethical aspects of the research. Later, a copy of the digital file of the Terms of Free and Informed Consent (TFIC) was sent by email. The interview started with a reading of the TFIC and recording of the participant's acceptance, in which the participants provided their full names and the number of their identity document. Later on, the audio file, with the participants' consent, was sent by email to each one of the participants.

The interviews were transcribed in full and reviewed, through repeated listening to the recordings. For the analysis, the researchers used thematic discourse analysis, in accordance with the proposal of the Discourse of the Collective Subject (DCS). ${ }^{18}$ This is a methodological proposal for the organizing and tabulating of qualitative data, which is based on the supposition that the collective thinking can be seen as a set of discourses on a given issue.
It is a discursive strategy which aims to throw light on the set of semantic individualities which are components of the social imaginary, thus being a way of making the collective speak directly. After skim-reading of the transcribed material, the Keyexpressions (KEs), which revealed the essence of the statement, and the Central Idea(s) (CI) which are a description of the meaning of a statement or of a set of statements were identified. The CI is a word or linguistic expression which reveals and describes in a summarizing, precise and accurate way, the position of a statement or set of statements which make up the DCS. ${ }^{18}$ Later, the DCS were constructed, composed of the KEs which have the same CIs, re-typed in the first person singular. The findings obtained underwent a process of peer validation regarding the opposing points and/or objections being discussed.

All the aspects involved in undertaking the research are in accordance with Resolution N. 196/96 of the National Health Council. The macroproject was approved by the Research Ethics Committee of the Santa Catarina State Department of Health, under protocol N. 0026.1602/09.

\section{RESULTS AND DISCUSSION}

The participants in this research were aged between 23 and 48 years old, and the majority were female. The time since qualification varied from 2 to 24 years, while the time they had worked in the service varied from seven months to 23 years. Of the 12 participants, only one was specialized in obstetric nursing, while three were finishing the course. The majority of the nurses' experience in obstetrics arose from their work in the service. Most did not work only in the obstetric center, being responsible for other departments of the institution.

The CIs emerged from the analysis of the nurses' accounts, and were grouped into three themes: "The professionals resist the presence of the companion"; "Lack of physical structure and human and material resources"; and, "The institution resists the implementation of the Companion's Law". The CIs and their respective DCS were identified with the same numbering.

\section{THEME I - The professionals resist the presence of the companion}

The health professionals' resistance to the presence of the companion will be presented in the five CIs below. 
CI1 - The companion's insertion depends on authorization from the doctors

DCS1 - In the birth, we are a little restricted due to some doctors. Some let the companion be there, some do not [...]. So, it is discussed with the doctor at the time, and it is decided if he may or may not go in [the companion] [...] It also depends on the state of the parturient woman. If the obstetrician authorizes it, the family member may accompany the woman. [...] Some doctors do not accept that the companion should be there because he is not paying into an insurance scheme which covers this. And when they say that the companion cannot go in, we say 'Doctor, you know about the Companion's Law', but they say 'the person laying down the law here, today, is me'. The decision here is made by the doctor.

CI1 and its respective DCS demonstrate that the decision-making power is held by the doctor, who determines the presence or not of the companion. In the discourse, it may be observed that the parturient woman's clinical state and the type of insurance coverage are used for explaining the decision making. However, in some situations, in an arbitrary way, what really prevails is the hegemonic power of the doctor, which overrides the right of the woman supported by the Law ${ }^{1}$ and by scientific evidence. ${ }^{9}$ The obstetricians' training, based in the use of interventionist techniques, often does not prioritize the humanization of the care practice. ${ }^{19}$ There also seems to be ignorance of the legislation extending the right to a companion to women using all the private obstetric health plans. ${ }^{4}$ In this context, the legality and the benefits of this practice are not enough to change the professional attitude.

\section{CI2 - The companion's insertion depends on the medical and nursing teams' evaluation}

DCS2 - [...] If the team agrees, the companion goes in. And we say 'ifeverything is calm' we let them, there's no problem at all. So it is evaluated, both by the nursing team and by the doctors, to see what they think. Generally, he [the doctor] does the evaluation, he does it like I do [the nurse] [...]. When the family member is nervous or stressed, he [the doctor] really does remove him. Sometimes, when she [the parturient woman] enters the delivery room, I [the nurse] ask him to leave, but that is because he [the companion] really is very nervous, or something like that.

In some situations, the decision-making process is shared with the nursing team (CI2 and DCS2). However, the nurse also has a gate-keeping role and comes to determine when the companion may or may not remain there. The professionals' resistance is one of the obstacles to the implementation of humanized practices, ${ }^{19}$ and the acceptance of the companion depends on the health professionals' decision. $^{20-21}$

Thus, it is demonstrated that the implementation of new practices causes resistance on the part of the health professionals, who do not understand that the changes, as well as being necessary, are beneficial for the clients and their family members.

\section{CI3 - The team fears being evaluated by the companion}

DCS3 - [...] As with any change, some professionals thought it was too complicated, and thought that they [the companions] would be evaluating them. [...] Fear of somebody from outside seeing something that you are doing, because, let us say, there is a bit of blood, for him [the companion] that is not 'normal', we feel. Sometimes [...] there are procedures which are slightly invasive, which will not be a 'normal', calm birth, [...] it will be an emergency birth, and they say that the companion, if present, would make people feel uncomfortable, all that. Maybe this is also a barrier to the Law being complied with.

The team's resistance to the companion is also related to the difficulty of providing assistance in his presence, especially during the interventions, which accentuates the feeling of being "supervised" (CI3 and DCS3). This may be due to the professionals having difficulty in accepting people from the woman's social support network in the care setting, or to their not feeling secure in undertaking techniques in the presence of other people. The insertion of this new person requires a "new" professional profile, which includes in its practice strategies which value the subjects' subjectivity and individuality, bypassing the vertical relationship between health professional and service user. The authoritarian attitude and asymmetric relationship between the health professionals and the service users contribute negatively, in a care perspective with a view towards the subjects' autonomy regarding their health. ${ }^{22}$

CI4 - Professionals with a greater length of service are more resistant to the presence of the companion

DCS4 - [...] The older professionals, they have a certain resistance to this insertion [of the companion]. 
The older staff don't have this vision, of letting the family member accompany the birth [...] They are a bit more resistant, which is a nuisance and everything, you know? Some, not all of them, have this idea, which gets in the way and all that. [...] They simply don't accept it.

In this context, it seems that the reasons indicated previously in the CIs become more intense, the more years are spent working in obstetrics, shown in DCS4, as the resistance to changes in care behaviors increases. It is possible that these professionals' training, prior to the policies of humanization ${ }^{5}$ and evidence-based practice, contributes to maintaining the model of care centered on the professional. The professionals' training remains distant from a comprehensive and humanized model of care, demonstrating shortcomings both in the academic training ${ }^{22-23}$ and in the continuous education of health workers. ${ }^{7,21-23}$ It is important for professional improvement to invest in training programs directed at the humanization of health practices and care for the service user, this being revealed to be necessary for the transformation of the biomedical care paradigm, present in the health services. ${ }^{22}$

\section{CI5 - The companion gets in the way of the obstetric center team}

DCS5 - They [the doctors] think that the companion is a nuisance. [...] that the companion is going to come, is going to talk, they think that the companion, actually, gets in the way... [...] that he will make work for the team, when they have to attend that person [the companion] who goes and feels dizzy or faints when he sees blood [...]. They [the obstetric center team] say [...] that as many people who were companions ended up feeling dizzy or fainting, [...] it ends up with them getting in the way, instead of being there helping at the time of the birth. [...] It also ends up stressing the team which is working. They [the obstetric center team] think that their time is not for humanizing or for providing guidance.

CI5 and its DCS demonstrate that the presence of the companion hinders the obstetric center professionals. The health professionals often carry preconceived negative ideas regarding the companion's presence in the birth setting. ${ }^{6}$ For the team, the companion increases the workload, as, in their view, he arrives unprepared, ${ }^{20}$ unaware of the physiology of birth or finding the procedures undertaken with the parturient woman in the care setting to be strange. This perception is associated with the technocratic model of care, established based on the institutionalization of birth, which follows a standardization in the care and a line of work which does not permit the disruption of hospital order and routines. ${ }^{11,20}$ the fact that the professionals consider the companion to "get in the way" may be related to the current model of care, centered on the professional, which does not promote the woman's protagonism and the participation of her social support network.

\section{THEME II - Lack of physical structure and human and material resources}

The CIs and the KEs, which resulted in the construction of the discourses, indicate that the health services have limits related to the environment, which limit the presence of the companion.

\section{CI6 - The physical structure of the hospital is not appropriate for the insertion of the companion}

DCS6 - The physical structure of the hospital is old [...] It is too small, there isn't a room for him to be in there during labor, for the companion. The space does not allow privacy for the parturient women, who can feel embarrassed with the other companions. Because, sometimes, the companion is a man, you know? [...] Even the CCIH [the Hospital Infection Control Committee] sometimes thinks it is not compatible, that there are too many people in the block. [...] It is the physical structure which, in my view, is not appropriate for this type of procedure. [...] It is not adequate for complying with this Law.

The services' physical limitations are factors which hinder the insertion of the companion..$^{24}$ Some hospitals' buildings have structures whose original plan does not allow extension, not fore-seeing the presence of somebody there, apart from the parturient woman. The distribution of the spaces also interferes with the privacy of the parturient women who, according to the nurses' discourse, can feel embarrassed by the presence of male companions. ${ }^{22}$ In some services, only female companions are permitted, limiting the parturient women's possibilities for choice. ${ }^{12}$ Other studies indicate the inadequacy of the physical structure to be one of the barriers to the implementation of humanized practices during the birth process. ${ }^{12,23,25}$ On the other hand, for the companions, difficulties related to the physical space and other environmental aspects do not represent obstacles to their being present or participating with the parturient woman, when they do not spend a long period of time in the service. ${ }^{24}$

In 2008, under RDC n. 36, the Brazilian health services received a period of 180 days to adapt their 
physical structure to accommodate the woman and her companion, so as to promote privacy and security in accordance with the principles of humanization. ${ }^{3}$ However, the nurses' discourse demonstrates that the hospitals have not yet managed to adapt to the directives. As a result, it is understood that the services investigated, as well as not having reformed or adapted their physical structure to receive the companion, use this fact as a rationale for impeding the companion's inclusion.

The belief in the fact that the companion, within the hospital space, may increase the risk of infections is also used as a rationale for limiting his presence, although there is no evidence corroborating this information. The principal causes of hospital infections are related to inefficient cleaning measures and invasive procedures related to obstetric care and cesarean births. ${ }^{26}$ Hence, the health team has an important role in advising companions regarding actions for preventing infection and adverse effects, such as hand-washing. ${ }^{27}$

\section{CI7 - Lack of staff hinders the companion's insertion}

DCS7 - Yes, we work with the minimum number of staff [...] And we cannot give the necessary attention to this companion. [...] For the woman, we manage to give the care and everything, but if, for some reason, the companion is not prepared for this... If it is very busy at that time, the team is agreed that he cannot be present. It is just a question of having the staff, the appropriate number of people, and it can be implanted easily, there won't be any other problem.

The estimation of human resources is anchored in attending the biological needs which the birth involves. Hence, the number of staff is insufficient for meeting the parturient woman's psychosocial needs, thus driving the companion away from the birth setting (CI7 and in DCS7). This aspect is also indicated in another study, ${ }^{13}$ in which a reduced team was one of the obstacles to the insertion of the companion in the obstetric center. The currently-dominant discourse is that once there is an increase in the number of professionals, there might be better acceptance of the inclusion of the companion.

\section{CI8 - Lack of gowns hinders the companion in the cesarean}

DCS8 - We have outfits, but not many, which are used for the functioning of the hospital, the hotel- ling services, and surgery. So, letting the companion join the birth means having to take what you need from another part of the hospital which needs it too [...] We don't have enough clothes to be making them available for other people who are going to be coming into the surgical center. Sometimes there are a lot of operations booked for the same day, so, because of clothing, the companion cannot be present. [...] So, sometimes, the companion is not present at cesareans.

The lack of material resources appears as one of the reasons limiting the presence of the companion, especially during cesareans, which require gowning-up with protective clothing (CI8). DCS8 exemplifies that there are other priorities within the service, with the presence of the companion being understood as less important and even expendable, faced with other aspects of the care. Thus, it is clear that these services, in addition to not complying with the Law, are not recognizing the benefits of this practice for the woman and the newborn.

\section{THEME III - The institution resists the implementation of the Companion's Law}

The CIs which refer to this theme refer to the managers' positioning regarding the presence of the companion in the care setting.

\section{CI9 - The institution has never promoted discussion regarding the Companion's Law}

DCS9 - We haven't had time to sit down and discuss this, not yet. It has never been discussed. They don't even accept you commenting about it. I don't know if they have ever sat down and talked about it. We did think about having a meeting but we haven't done it.

Although the health professionals have an important role in implementing humanized care, the managers' participation is necessary for putting these practices into effect in the health services. ${ }^{22}$ Discussion of the Law in the institutional space could be a strategy for facilitating the insertion of the companion into services and, consequently, for contributing to the parturient women's satisfaction. ${ }^{10}$

The absence of collective meetings, promoting dialog about the inclusion of this new person during the birth process, as emphasized in CI9 and its respective DCS, reflects the lack of institutional positioning for implementing the $\mathrm{Law}^{1}$ and the Ministry of Health directives, ${ }^{3}$ which are, at the present time, supported in the current strategy for 
women's health care. ${ }^{6}$ This situation is shown to be worrying, as the manager has a fundamental role in promoting institutional changes which can contribute to the incorporation of humanized care practices.

\section{CI10 - Lack of institutional support and directives}

DCS10 - I think this has a lot to do with [...] the hospital administration. Because they think that, if there is a companion, it is more costs [...]. We hold discussions [...] which is a right [...] But we have situations in which the patient's insurance policy doesn't give this right. Here, we work with significant financial difficulties. So, the people from administration try to cut anything which creates costs here for us.

In some services, the administrators decide not to allow the presence of the companion, even considering the benefits of his presence for the parturient woman ${ }^{7,9-10}$ and considering the Law. ${ }^{1}$ Financial difficulties cause the managers to direct the budget towards what they consider to have more priority. Thus, the companion is not included, but is discarded as something "expendable". There is a mistaken understanding that some health insurance plans do not cover expenses to do with the companion and that the woman is not guaranteed this right. Normative Resolution N. 211 of $2010^{4}$ is fairly clear in authorizing charging for the expenses with the companion's stay and accommodation, not justifying the institutional decision to impede the presence of the companion with the woman.

These findings demonstrate that the health service managers are not always concerned with applying the directives of public policies. On the other hand, there is no strategy for monitoring and assessment by the responsible bodies, and, at the same time, one can observe the lack of social control such that these changes may actually take place.

\section{CONCLUSION}

The nurses' discourses demonstrate that there are still obstacles to the implementation of the Companion's Law in some health services in Santa Catarina. The limitation of this right is not consistent with the principles guiding the SUS: equality, comprehensiveness and universality.

The difficulties are related not only to the professionals' decisions regarding the insertion of these new subjects in the birth setting, but also to the lack of organizational structure in those institutions which did not adapt.

The acceptance and inclusion of the companion depends not only on changes of attitude among the professionals, but also on institutional support and management strategies which will value care centered on the service user. Because of this, it is important that the managers provide spaces for discussion with the institution's administrative and care staff, investigating the potential and weaknesses of the resources available for implementing the Law. The management model must encourage the participation of the health professionals, such that the planning may include strategies for resolving the difficulties impeding the extension of this right to all parturient women. In addition to this, it is important for managers to know the public policies referent to women's health, for them to seek resources and establish partnerships for adapting the service, and for them to promote continuous education.

It is also fundamental for health professionals who work in both the hospital ambit and at other levels of care to join forces for implementing the Law, empowering women and their families such that they may demand this Law be observed.

\section{REFERENCES}

1. Brasil. Lei n. 11.108. Altera a Lei n. 8.080, de 19 de setembro de 1990, para garantir às parturientes o direito à presença de acompanhante durante o trabalho de parto, parto e pós-parto imediato, no âmbito do Sistema Único de Saúde - SUS. Diário Oficial da União - 2005; 8 abr.

2. Portaria n. 2.418 de 2 de dezembro de 2005. Regulamenta a presença de acompanhante para mulheres em trabalho de parto, parto e pós-parto imediato nos hospitais públicos e conveniados com o Sistema Único de Saúde. Diário Oficial da União (Brasília). 2005; 06 dez.

3. Agência Nacional de Vigilância Sanitária (BR). Resolução da Diretoria Colegiada RDC n. 36/2008. Dispõe sobre Regulamento Técnico para Funcionamento dos Serviços de Atenção Obstétrica e Neonatal. Republicada em 11/07/2008. Brasília (DF), 2008.

4. Agência Nacional de Saúde Suplementar (BR). Resolução normativa n. 211. Atualiza o Rol de Procedimentos e Eventos em Saúde, que constitui a referência básica para cobertura assistencial mínima nos planos privados de assistência à saúde. Diário Oficial da União, Brasília (DF), 2010; 11 jan.

5. Ministério da Saúde (BR). Programa humanização 
do parto: humanização do pré-natal e nascimento. Brasília (DF); 2002.

6. Portaria n. 1.459/GM, 24 de junho de 2011. Institui, no âmbito do Sistema Único de Saúde, a Rede Cegonha. Brasília (DF): MS; 2011.

7. Brüggemann OM, Parpinelli MA, Osis MJD. Evidências sobre o suporte durante o trabalho de parto/parto: uma revisão da literatura. Cad Saúde Pública. 2005 Set-Out; 21(2):1316-27.

8. Organização Mundial da Saúde (OMS). Maternidade segura: atenção ao nascimento normal - guia prático. Genebra $(\mathrm{CH})$ : Organização Mundial da Saúde, 1996.

9. Hodnett ED, Gates S, Hofmeyr GJ, Sakala C, Weston J. Continuous support for women during childbirth. Cochrane Database of Systematic Reviews [página na internet]. 2012, issue 10 [acesso $2014 \mathrm{Fev}$ 17]. Disponível em: https://childbirthconnection.org/ pdfs/CochraneDatabaseSystRev.pdf

10. Brüggeman OM, Parpinelli MA, Osis MJD, Cecatti JG, Carvalhinho Neto AS. Support to woman by a companion of her choice during childbirth: a randomized controlled trial. Reprod Health [online]. 2007; 4(5):[7 screens]. Disponível em: http:/ / www. ncbi.nlm.nih.gov/pmc/articles/PMC1936417/

11. Holanda VR, Abreu DWM, Holanda ER, Cabral RWL. Avaliação da assistência obstétrica no Estado da Paraíba à luz das normas sanitárias. RSD. 2011 Out-Dez; 35(91):624-33.

12. Souza TG, Gaíva MAM, Modes PSSA. A humanização do nascimento: percepção dos profissionais de saúde que atuam na atenção ao parto. Rev Gaúcha Enferm. 2011 Set; 32(3):479-86.

13. Carvalho IS, Costa Junior PB, Nunes VMA, Macedo JBPO. Dificuldades relacionadas à presença do acompanhante durante o processo parturitivo da mulher: percepção dos enfermeiros. Rev Pesqui Cuid Fundam. 2011 Dez; (suppl:28-36).

14. Creswell JW. Projeto de pesquisa: métodos qualitativo, quantitativo e misto. 2 ed. Porto Alegre (RS): Artmed; 2007.

15. Brüggemann OM, Oliveira ME, Martins HEL, Alves MC, Gayeski ME. A inserção do acompanhante de parto nos serviços públicos de Santa Catarina, Brasil. Esc Anna Nery Rev Enferm. 2013 Jul-Set; 17(3):432-8.

16. Fontanella BJB, Ricas J, Turato ER. Amostragem por saturação em pesquisas qualitativas em saúde: contribuições teóricas. Cad Saúde Pública. 2008 Jan; 24(1):17-27.

17. Sony Sound Forge: digital audio editor [programa de computador]. Version 9.0. Sony; 2008.

18. Lefrève F, Lefrève AMC. Discurso do sujeito coletivo: um novo enfoque em pesquisa qualitativa (Desdobramentos). Caxias do Sul (RS): EDUCS; 2003.

19. Malheiros PA, Alves VH, Rangel TSA, Vargens OMC. Parto e nascimento: saberes e práticas humanizadas. Texto Contexto Enferm. 2012 AbrJun; 21(2):329-37.

20. Santos LM, Carneiro CS, Carvalho ESS, Paiva MS. Percepção da equipe de saúde sobre a presença do acompanhante no processo parturitivo. Rev RENE. 2012; 13(5):994-1003.

21. Longo CS, Andraus LMS, Barbosa MA. Participação do acompanhante na humanização do parto e sua relação com a equipe de saúde. Rev Eletrônica Enferm [online]. 2010 [acesso 2011 Set 11]; 12(2):38691. Disponível em: http:/ / www.fen.ufg.br/revista/ v12/n2/v12n2a25.htm

22. Nagahama EEI, Santiago SM. Práticas de atenção ao parto e os desafios para humanização do cuidado em dois hospitais vinculados ao Sistema Único de Saúde em município da Região Sul. Cad Saúde Pública. 2008 Ago; 24(8):1859-68.

23. Busanello J, Kerber NPC, Fernandes GFM, Zacarias CC, Cappellaro J, Silva ME. Humanização do parto e a formação dos profissionais da saúde. Cienc Cuid Saúde. 2011 Jan-Mar; 10(1):169-75.

24. Frutuoso LM. Percepções do acompanhante acerca da experiência e dos aspectos organizacionais relacionados à sua permanência no centro obstétrico. Florianópolis. [Dissertação]. Florianópolis (SC): Universidade Federal de Santa Catarina; 2011.

25. Corrêa ACP, Arruda TM, Mandú ENT, Teixeira RC, Arantes RB. Humanização da assistência à puérpera: concepções de profissionais de enfermagem de um hospital público. Cienc Cuid Saúde. 2010 Out-Dez; 9(4):728-35.

26. Benicasa BC, Walkerl C, Cioba C, Rosa CCS, Martins DE, Dias E, et al. Taxas de infecção relacionadas a partos cesáreos e normais no Hospital de Clínicas de Porto Alegre. Rev HCPA. 2012; 32(1):5-9.

27. Allegranzi B, Pittet D. Role of hand hygiene in healthcare-associated infection prevention. J Hosp Infect. 2009; 73(4):305-15.
Correspondence: Odaléa Maria Brüggemann

Federal University of Santa Catarina, Health Sciences Center

Campus Universitário, Nursing Department

88040-900 - Florianópolis, SC, Brazil

Email: odalea.ufsc@gmail.com
Received: October 04, 2013

Approved: April 03, 2014 